\title{
Theatre as Research - A Mysterious Mix
}

\author{
Jocene Vallack \\ James Cook University
}

\begin{abstract}
The Australian Curriculum mandates that Arts will be taught as part of the Foundation to Year 10 program in schools. My background as a Theatre-in-Education performer and as a Drama teacher has informed an approach to doing research with children, which involves making up plays about local stories. Firstly, local folk are interviewed and their anecdotes are recorded as data. The children then analyse and interpret the data, as a group, with the help of their teacher. It is then synthesised into a written play script. I have found this Theatre as Research approach to be a wonderful tool for integrating the teaching of local history with the Arts. It also has potential to strengthen community bonds and enhance inter-generational communication. Once the play has been created, the storytellers are invited as audience members to see their lives played out on stage.

The paper will relate examples of how I have performed ethnographic Drama with various secondary and tertiary students to facilitate and present research. It will then offer a step by step approach for doing Theatre as Education.
\end{abstract}

\section{Introduction}

$\mathrm{T}$ his paper will present a methodology, which I call Theatre as Research. It is informed by an approach I have been developing into a research methodology. The Theatre as Research methodology framework (Vallack, 2015) informs the methods of data collection, analysis and interpretation. So far, I have used the approach with secondary school students and pre-service teachers, to collect narrative data for analysis from the wider community. After the locals tell their stories, the interpreted data and results are played back to them in the form of a theatre performance. Socially and aesthetically, these stories, which in script form are a heightened representation of truths told, allow the original storytellers to see their recollections come to life as theatre. It gives factual and sentimental recognition to the lives of the co-researchers. From a methodological viewpoint, audience feedback facilitates opportunity for member-checking of results and ongoing, organic research.

Using Art in research and doing Art for its own sake are very different activities. I teach Art in Education to preservice teachers. Each year, some of my explicit-learning devotees say to me, "Just tell me what to do to get a high mark, and I will do it." I tell them that they will 
need to surprise me. They find this annoying, but they need to think beyond the safe models to engage in the risky behavior that is innovation through Art. Creativity is a venture into the unknown, and although academic circles are again beginning to pay lip-service to creativity, curriculums are still locked down with predictable, outcome-based pedagogies. A spontaneous step into the unknown may be risky, not least of all because we won't know how to assess it. However, Art and Research are not the same in that artists may let the Art speak for itself, but researchers must be able to explain themselves.

\section{What is the difference between Art and Research?}

- Art speaks for itself

- Art is interpreted subjectively

- Art can be know through both magical and mythical consciousness, as well as mental consciousness (astre, 198e)

- Art speaks through symbol and metaphor
- Research is explained

- Research is interpreted with the bound of a theoretical framework, which can be argued to be philosophically aligned and cognizant of its limitations

- Research may use magical and mythical consciousness as process, but must be explained rationally in the end (vellsck, 2014]

- Symbol and metaphor informing the research must be explained hermeneutically

Conference slide 1. The difference between Art and Research

I argue that Slide 1 summarises some key differences between Art and research. I have experienced a broad range of arts-based approaches to research and some of them met the rigorous requirements of research. Installations, Dance interpretation of data and Autoethnography (Ellis, 2004; Ellis, Jones, \& Adams, 2013) can count as research when the author is able to explain the methodological framework in terms of its philosophical alignment. Research must be able to validate why each method was relevant within the given context, and why the chosen approach was best suited to answer the research question. It is with this commitment that I now set out the theoretical framework for Theatre as Research: 


\section{Theatre as Research: THEORETICAL FRAMEWORK}

\section{- epistemology \\ - tHEORETICAL PERSPECTIVE \\ - METHODOLOGY \\ - METHODS \\ 1. EXPERIENCE: \\ 2. ROLEPLAY: \\ 3. SCRIPT: \\ 4. PERFORM: \\ 5. MEMBER CHECK:}

6. REPEAT:

\author{
Constructionism \\ Postmodern Interpretivism
}

Theatre as Research

\author{
Allow themes to emerge through roleplay and \\ improvisation. \\ Synthesise themes and make logistical script sense \\ of the meanings \\ Perform play for the originalstorytellers-theco- \\ researchers \\ Discuss and record feed back on the integrity of the \\ interpretation of data given. Was it true to the \\ spirit of the thing? Wasit an authentic retelling \\ from the perspective of the originators? \\ Repeat process for ongoing research
}

Conference slide 2: The theoretical framework of Theatre as Research methodology

Art, specifically the performing arts play-making process, demands the higher learning skills of creating and synthesising. (CELT, 2015). This Theatre as Research approach, in particular, involves basic data being interpreted, synthesized and reconstructed to form new insight. Moreover, art engages ancient ways of knowing - the magical and the mythical (Gebser, 1986). In line with Jean Gebser's Evolution of Conscousness (Gebser, 1986), I argue that by engaging both emotionally and cognitively with knowledge, learning becomes intrinsically incorporated into one's perception. The process of making up plays based on local anecdotes and oral histories, is both valid research and engaging pedagogy. It takes learning beyond the explicit (what happened) into the realms of synthesizing (how can we logistically fit these ideas into the play?) and the creative (how can we represent this recurring theme visually and symbolically?) Best of all, it involves authentic problem solving, and students work with clear purpose rather than clear instruction.

Using the Theatre as Research model, I have produced several plays based on oral histories. The act of creating theatre in education is not new, but defining the activities in terms of research methodology is in its infancy. I believe that many arts-based researchers need to be more rigorous about the research models they adopt, in order to authenticate their artistic outcomes as valid research. Much of this is semantic, but logic relating to the conditions in which a system or theory can be said to be true is essential to research methodology. As a researcher. I must be able to articulate and validate my choices. If I was just doing Art, I could leave that work to others. 
I will now describe examples of theatre as research and explain how I approach creating theatre as research within a classroom and community context.

\section{An Example of Theatre as Research}

When I was teaching Drama to Secondary students in a small, Victorian country town, we embarked on a cross-generational project, which involved senior students visiting older folk at the day-care centre, to ask them about their memories of their own adolescence. This was a small, country town: Population 800. Many of the older folk had grown up and lived there all of their lives, as indeed, some of those former-students now do. The sixteen year olds asked the octogenarians what it was like in their town when they were sixteen. The stories took us back to pre-second world war. The stories not only embodied retro sentiment, but a proper shift back to traditional values:

One lady told that she had worked in her parents' General Store. At fifteen she fell in love with a local boy, but she was not able to marry him, due to her domestic and family responsibilities. Later, her parents became ill, and the lady (to whom we assigned the character name of Grace) continued to work in the store for decades, until her parents finally passed away. The lad had waited for her - for thirty-five years, and they married when Grace was fifty. When the school students interviewed 'Grace', she was eighty-five and lamenting the recent death of her beloved husband. We related the story as tenderly and respectfully as possible, and 'Grace' loved the show. She had seen her life played out, and she thought we had captured the nuances accurately, she said.

Children who practice Theatre as Research within their community can achieve rich learning including community awareness, interview and communication skills, empathy through process Drama, analytical skills through data interpretation, dramatic skills, narrative skills, comprehension and listening skills, the ability to isolate themes from data, as well as a strong sense of belonging - to a theatre group, a school and the wider community into which the research penetrates. If I had to draw up an assessment rubric for this learning task I would do what we usually do in the arts - draw an approximation of part of the learning and just know that the real strength of the task may well lie beyond the rubric fence line - where the wild things are. These are the things that draw us to them intrinsically, for no measurable gain, and which will always elude finite evaluation.

Here is a sample of the text that was written via a process of improvisation based on the original stories. In research terms, it is an analysis and synthesis of the primary data:

Excerpt from A Penny for Your Thoughts (Vallack, 2015)

The troupe enters as neutral actors, and then proceed to the start the play they have assembled to rehearse - "You Don't Get Much For a Penny These Days". This play is also presented non-naturalistically, but there are moments of emotional truth. Vera Lynne's "Lily Marlene" plays as actors arrange set. The red painted modules, the doorframe and an imaginary table are moved into place by the actors. Characters of Grace and Tammy take up positions. Grace begins to dust the shop. Tammy dons costume in view of audience, then enters. 
Grace: Morning Tammy.

Tammy: Morning Grace.

Grace: What can I do for you today Tammy?

Tammy: I'd like a farthing of them please.

Grace: These?

Tammy: Yes please. And a ha'penny of them. Um...How much are they?

Grace: Two for a penny.

Tammy: No...a halfpenny worth of them. What are they at the top Grace?

Grace : Right at the top?

Tammy: Yes.

Grace: They're aniseed balls - eight for a penny.

Tammy: Yes, I'll have two please.

Grace: You're up to a penny ha'penny.

Tammy: OK, here. Bye.

Grace: Bye. See you next Friday

Tammy: I'll have a whole twopence to spend then! Grace looks horrified.

Exit Tammy.

Lewis: 'Morning Grace. Gee, that kid takes her time, doesn't she! Grace" 'Sure does. I think she takes more time to spend a penny than most people take to spend a pound.

Lewis: Has the formalin that Dad ordered come in yet?

Grace: Yes, I'll just get it from out the back. Your father's ordered a fair bit of this lately. This flu epidemic is really tragic.

Lewis: The town's not itself - there are no dances any more they've even closed the skating rink.

(Pause) 
You look really nice today, Grace.

Grace: Thank you, Lewis.

Lewis: $\quad$ You must really miss the dances.

Grace: No. I didn't really have anyone to go with.

Lewis: Well, when they start again, maybe you will. (Pause) I'd better get this back to Dad.

Grace: I'm glad you're not in the funeral business, Lewis.

Lewis: $\quad$ No need to worry about that - George is a good worker. Dad doesn't need anyone else.

Enter Dad, tired of waiting for Lewis.

Dad: What's taking so long, Lew? (He knows what's taking so long.)

Lewis: Oh, nothing. 'Just talking.

Dad: $\quad$ Good morning, Grace.

Grace : Good morning, Mr Beck.

Dad: Lewis, George has quit - I'm gonna need your help son.

Lewis: George? Why?

Dad: This flu epidemic is bad, Lewis. He says he wants to get his family back to Broken Hill before it gets any worse. He's just scared, I guess. There's no need - the formalin kills any infection. We're not scared though, are we son!

Lewis: No Dad.

Dad: $\quad$ OK then. Good day, Grace.

Exit Dad

Lewis: $\quad$ Actually, I am a bit scared, Grace.

Grace: $\quad$ So am I.

Exit Lewis 


\section{How to do Theatre as Research}

The researchers, who may be Drama students, pre-service teachers or anyone with an interest in arts-based research, approach a sector of the community and collect stories in the firstperson. This is the primary data that will underpin the research. For example, when I was a volunteer lecturer in qualitative methodology at a university in Tanzania, I asked postgraduate students to interview older village folk about their lives, hopes and loves. The stories were fashioned into the first publication for St John's University in Dodoma (Vallack, 2012), offering primary data about the social, political and cultural climates in Tanzania. It is a performance text. The stories were astonishingly candid and evoked emotion as well as thought, because the research methods did not censor vulnerability. Older folk related stories of the Ugandan war, forced marriage, female circumcision and lion attack, with the full emotional impact that can be expressed through Art. Art informs us through research in ways that are not accessible to positivist science.

After the narratives have been collected, art-making strategies are used to combine them somehow into a comprehensive, dramatic text. The Tanzanian stories, so powerful in their own contexts, were left whole and presented as a series of monologues. Most actors or directors will intuit the way to tell the story without diminishing it, and the sort of researcher attracted to this kind of work will probably have those skills. Some artistic license may be used, to embody data that can be synthesized into one character instead of several, as appropriate. This is an Arts convention common throughout many societies anyway ANZAC's unnamed soldier, for example, can symbolise a universal truth common to many individuals.

The next step is to return to the rehearsal room and improvise dialogue to support the presentation of the scenarios described by the participants. Keeping to factual details, such as exact times and places, is less important than authenticity in subtext and emotional truth. It is the universal truth that matters, not the incidental details. Whereas quantitative methods better serve finite facts, Theatre as Research facilitates empathy with the characters. Husserl, the founder of Phenomenology, bases the whole of his theory of transcendental phenomenology on the idea that the most subjective experiences will bring scholars to the most universal insights, through the transformation, which he calls intersubjectivism (Husserl, (1964/1929) ). He explains that, "Subjectivism can only be overcome by the most all-embracing and consistent subjectivism (the transcendental). In this (latter) form it is at the same time objectivism (of a deeper sort)..."(McCormic \& Elliston, 1981; Vallack, 2010)

Renowned psychologist, Milton Erikson agrees. He puts it this way:

The conscious mind understands the logic of it, and the unconscious understands the reality....The unconscious is much smarter, wiser and quicker. It understands better....it will protect you...(Bolduc, 2016)

Theatre as research aims to marry the subjective with the intersubjective, the conscious with the unconscious and the performing arts with research. When the rational and creative aspects 
of the mind are able to work together, as they do in authentic arts-based research, then knowledge is vigorous.

I have argued that Art speaks for itself. It does not matter if, as the artist, I understand what my work is conveying to others. Art is manifested from the unconscious, and never needs to be rationalized by the artist. On the other hand, Research is a rational process. When I engage Art as part of my methodology, I may be generating data from unconscious image and symbol, but at some stage I will need to be able to explain myself. I will need to explain the meanings of the symbols, according to my analysis, the methodological process I have chosen and why I think it is the most appropriate approach to my research question, and I will need to discuss, logically and rationally, the research results.

In conclusion I would like to emphasise the advantages of using theatre as Research methodology. Not only does theatre immediately engage a wider audience than the average academic paper, but it facilitates the opportunities for member-checking and clarification of data interpretation through audience feedback opportunities. The research inspired by such a collaborative, community approach may be ongoing for as long as there is an interest in developing further research.

I believe it is significant when there is opportunity for research to engage an audience both emotionally and intellectually. Allow me to leave you with this quote from Milton Erikson:

"We have our affective, or our emotional life, and we have our cognitive, or intellectual life. And we are taught from the very beginning to emphasise our intelligence as if it were really the important thing. But the important thing is the person on all those levels....You are letting your intellect interfere with your learning. We all have so much knowledge of which we are unaware."(Bolduc, 2016)

\section{Works Cited}

Bolduc, H. L. (2016). The words of Dr Milton H. Erickson. Retrieved from http://www.henrybolduc.com/erickson1.html

CELT. (2015). A revision of Bloom's Taxonomy of educational objectives. Retrieved from http://www.celt.iastate.edu/teaching-resources/effective-practice/revised-bloomstaxonomy/

Ellis, C. (2004). The ethnographic I: A methodological novel about autoethnography. Walnut Creek, CA: AltaMira Press.

Ellis, C., Jones, S. L. H., \& Adams, T. (Eds.). (2013). Handbook of Autoethnography. Walnut Creek, CA: Left Coast Press. 
Gebser, J. (1986). The Ever-Present Origin (N. Barstad and A. Mickunas, Trans.). Athens, $\mathrm{OH}$.: Ohio University Press.

Husserl, E. (1964/1929). The Paris Lectures. The Hague: Martinus Nijhoff.

Ludecke, Michelle. (2015) Lessons Learnt from Dancing the Data. AARE Conference Presentation. 2/12/15. Fremantle, WA, Australia.

McCormic, P., \& Elliston, F. (1981). Husserl. Shorter Works. Notre Dame, IN: Notre Dame University Press.

Vallack, J. (2010). Subtextual Phenomenology: A Methodology for Valid, First-Person Research. The Electronic Journal of Business Research Methods, 8(2), 109-122.

Vallack, J. (2012). News from Dodoma. Creative Approaches to Research, 5(1).

Vallack JM (2015) Theatre as education. Proceedings of the Australian Association for Research in Education Conference. In: AARE 2015: Australian Association for Research in Education Conference, 29 November - 3 December 2015, Freemantle, WA, Australia. 